\title{
Implementation of Ecotourism Empowerment in Coastal Border of West Kalimantan
}

\author{
Toto Sugito ${ }^{1}$, Adhi Iman Sulaiman ${ }^{1}$, Ahmad Sabiq ${ }^{2}$, Bambang Kuncoro ${ }^{2} \&$ Muslih Faozanudin $^{3}$ \\ ${ }^{1}$ Department of Communication Science, Jenderal Soedirman University, Indonesia \\ ${ }^{2}$ Department of Political Science, Jenderal Soedirman University, Indonesia \\ ${ }^{3}$ Department of Public Adminsitration, Jenderal Soedirman University, Indonesia \\ Correspondence: Toto Sugito, Department of Communication Science, Jenderal Soedirman University, Indonesia
}

Received: September 27, 2019; Accepted: October 13, 2019; Published: October 17, 2019

The research is financed by Ministry of Research, Technology and Higher Education of the Republic of Indonesia and Institute for Research and Community Services of Jenderal Soedirman University.

\begin{abstract}
Development must be an important and strategic priority, especially in the coastal border village area to prevent economic disparity, community conflict, and national disintegration. The research aims to analyze the implementation of the empowerment of coastal border of West Kalimantan. The research used qualitative methods of Participatory Learning and Action (PLA), data were collected through in-depth interviews, observation, documentation analysis, and Focus Group Discussion (FGD). The research took place in the coastal border area of Temajuk Village, Paloh District, Sambas Regency, West Kalimantan. Informants heve been purposively selected namely activists, students, community leaders, village government, business groups, academics, and tourists. The research analysis through interactive models by collecting data, reduce, verification, categorization and conclusions. The results showed that (1) Implementation of empowerment can be carried out by conducting counseling and training so as to increase awareness, motivation, knowledge, skills and solidarity between participants from the younger generation who form ecotourism community development. (2) Community development has been successfully formed from a young generation with the name "The Borneo tail" to become an activist who preserves and manages the potential of ecotourism by having the spirit of being a public relations (tourism guide), promotional and marketing services, and typical food and beverage entrepreneurs. (3) Development must continue to be improved, namely road infrastructure, availability of electricity and access to telecommunications networks (internet) as a support in the development of ecotourism, especially in Temajuk Village which is still limited and dependent on Malaysian territory. (4) The village and regional governments, academics, activists of empowerment, environmentalists and tourists need to collaborate in carrying out sustainable ecotourism empowerment programs for Borneo tails as community development.
\end{abstract}

Keywords: coastal border, community empowerment, development, ecotourism, participatory

\section{Introduction}

Development in the outer areas of the coastal border becomes important and strategic because it involves the image of the country in the frontier, remote and backward areas of social security, strengthening of the coastal economy, food sovereignty and maritime affairs. According to several studies, such as according to Van Geenhuizen and Rietveld (2011) land borders and coastal sea areas become important and interesting studies to be able to construct historical differences, the development process, the process of interaction between border areas and economic development, so that they can be an important note for consideration and planning for the future. Excerpts from Dharmasaputra (2009), Khairunnisa et al. (2017), Firdaus and Rahadian (2018) showed that there a lot of economic potential, especially fisheries and tourism commodities in the prospective coastal border areas. Therefore they need to be developed seriously and wisely by maintaining, preserving and developing the potential to create prosperity for the community, moreover the development in the coastal border areas is so important, strategic and characterizes the development of a nation.

Based on the results of the author's in 2018-2019 namely the potential of natural beauty and coastal-based tourism and fisheries have not been optimally developed, it only meets daily needs, less managed into a large-scale 
professional fisheries business according to export market demand, has not yet processed fishery products into restaurants or special foods for tourists, especially residents of Temajuk Village only work as workers in tourist sites for lodging and restaurant owners come from outside the area, thus it has not produced economic prosperity in the village community. The economy of rural communities is still dependent on Malaysia's neighboring countries, namely as farm laborers in oil palm plantations, rubber plantations, livestock, construction laborers, carpenters, and domestic servant. Many ecotourism potentials such as mangrove forests, and processing of food from mangrove fruit, sea turtle breeding, were unplanned, unwell-managed and unwell-organized beach tourism. There are problems in the border area development infrastructure such as the gap of transportation road facilities that are still not good.

According to Nugroho (2011) assert that there are still problems with the lack of infrastructure that can support to increase economic productivity for welfare and security guarantees as well as the lack of implementation of empowerment programs in the outer border areas. According to Witarsa (2015) there are some complex problems in the coastal border areas such as lack of knowledge and ability in managing coastal resources, especially from socioeconomic, biophysical, market, technology and institutional and technological aspects. While Hassan and Rahmat (2016) emphasize the vulnerability of environmental damage and the potential threat of disasters in coastal areas will hamper people's economy, thus local communities must be prepared to anticipate this.

Various attempts have been made by the government to issue Law Number 26 of 2007 concerning Spatial Planning, which is followed up in Republic of Indonesia Government Regulation Number 26 of 2008 concerning National Spatial Planning, that border areas are strategic areas and their spatial planning priorities are prioritized in the implementation of development. Furthermore, Law Number 6 of 2014 concerning villages, particularly Article 13, states that the government can initiate the formation of villages in areas that are specific and strategic in the national interest, meaning the outermost areas within border regions between countries. According to the Master Plan for the Acceleration and Expansion of Indonesian Economic Development (MP3EI) 2011-2025, Indonesia as a maritime country has a target, among others, to focus on basic services in disadvantaged, remote and border areas in the framework of equitable development by increasing connectivity, inclusive and equitable development.

So that researchers are interested in analyzing the empowerment of young people in the development of ecotourism in the coastal border area in Tamajuk Village, Paloh District, Sambas Regency, West Kalimantan Province, which has the potential for natural tourism and a very beautiful beach that borders directly with the Sarawak region of Malaysia.

\section{Method}

Preliminary studies have been conducted by researchers in 2018, there are potential threats and disruptions of bilateral relations at the border on security and political aspects, especially regarding violations in the management and exploitation of natural resources across national borders, national boundaries and land boundaries of plantations and fishing areas. The young generation in this case students in the village community still lack of knowledge, understanding and skills in the management and development of the economic potential of environmental tourism of Temajuk Village cost which is very prospective.

So as further research, carried out the qualitative research methods of Participatory Learning and Action (PLA) that are relevant to research activities for the learning process, planning, counseling, training, mentoring, and developing that involve groups and communities in a participatory manner to explore issues and potential in depth and foster participation (Pretty et al. 1995); (Kumar 2002). Data were collected through in-depth interviews, observation, documentation analysis, and Focus Group Discussion (FGD). Participatory research is designed to construct experiences, knowledge, and skills and learn together in joint activities based on research questions such as problems, potentials and prospects about the preservation and development of ecotourism.

The informants who participated in the implementation of ecotourism empowerment were 25 people from student high school of Temajuk Village. While the expert informants from activists and academics who also became the instructors of empowerment activities were 4 people, and informants from the village apparatus there are 4 people and from community leaders 5 people.

The study uses interactional analysis by collecting data, reducing, verification, categorizing and drawing conclusions. The research analysis through interactive models by collecting data, reduce, verification, categorization and conclusions (Miles et al. 2014). 


\section{Results}

\subsection{Reserach Process of the Ecotourism Empowerment in the Coastal Border Village}

The research used qualitative research methods of Participatory Learning and Action (PLA), the stages process of program planning to implementation and monitoring and evaluation of implementation are important set of results, analysis and research discussion. This can be constructed based on the results of the 2018-2019 study which contained several major problems, namely the community of Temajuk Village still has a dependency in meeting their daily basic needs and earning a living by working in Malaysia as a farm laborer, fisherman, carpenter and building maker. The potential of natural and beach tourism as well as marine fisheries income has not been maximized as a community economic endeavor, but rather is being utilized by investors who buy land for lodging and restaurant services at tourist sites, while local people are only employees. Then the researchers conducted further research by first socializing and discussing empowerment programs as a recommendation for the results of the 2018 research to community leaders, empowerment activists, academics as experts and colleagues and village government using the Participatory Decision Making (PDM) method.

The result is recommending to carry out ecotourism empowerment to form young groups concerned about the environment and tourism with the target of student high school in Tmajuk Village with the aim of (1) students have high motivation, attention, concern and participation in participating in the empowerment process for the preservation and development of ecotourism-based tourism. (2) Students as the next generation have the opportunity to determine the future, namely protecting, preserving and developing the potential of the environment, tourism and rural economy, so that they are no longer dependent on neighboring Malaysia. (3) The village government, schools and activists of empowerment strongly support the activities of ecotourism empowerment among students.

Various references refer to the importance of the role of the young generation in development and empowerment, according to Wibawa (2013) youth have characteristics as people who have high spirits, idealism, dynamic, and are quick to accept changes so that they can be used as good development cadres. Okoli and Okoli (2013) stated the need for entrepreneurial empowerment for young people as a way to equip the skills needed to start a business independently and reduce the high unemployment. Itika (2011) states that the youth generation is the hope of the future and the nation's assets to be able to increase human resources through empowerment and education. Oyekan (2015) states that the youth generation is the hope of the future and the nation's assets to be able to increase human resources through empowerment and education.

El Hasanah (2015) and Raheem (2016) explained that the younger generation is a productive and creative resource so that they can open self-employment or sustainable self-employment as to reduce the unemployment rate and increase economic development. Wulandari (2016) states that the younger generation needs to be given wider opportunities to be motivated in bringing out creative ideas and developing their potential and interest in the process of development and empowerment. Bintari and Darmawan (2016) explain that youth are given learning to be able to know, understand and appreciate cultural traditions as values of local wisdom, then given a variety of education and training to develop their potential and interest to work. Ashary (2016) suggests that youth need to be given many opportunities to get empowerment through entrepreneurship training that is more applicable to skills in opening economic businesses and employment.

The research process to design and develop an ecotourism empowerment program on the coastal border villages is carried out through several participatory stages, namely:

(1) Formulating a program based on preliminary studies both literature review results of journal reviews, research results, mass media report, and scientific discussion studies with colleagues, experts and practitioner.

(2) Opening access and licensing of activities to the location in order to get permission, support and participation of all parties, both village government, schools and community leaders or activists.

(3) The third stage is designing an empowerment program through observation, documentation, study and dialogue with the community, community leaders and activists, academics and business people.

(4) Socialization of empowerment programs that have been designed to target empowerment, namely schools and empowerment activists.

(5) Implementation of ecotourism empowerment for young generationin coastal border villages to increase motivation, knowledge, understanding, care, ability to maintain, preserve and develop the potential of natural tourism (ecotourism), special food (culinary) and promotional and marketing strategies ecotourism. 
(6) Assistance, monitoring and evaluation of activities are carried out when the process of implementing empowerment is done by direct observation, informal and formal interviews or dialogue in a special evaluation forum, distributes the evaluation questionnaire to be processed, analyzed and the results presented to participants for further action. Moreover after the completion of activities are made important notes for improvement of the implementation of further better empowerment.

(7) Opening partnership access with local empowerment activists and schools so that they can continue the results of the economic empowerment and ecotourism program in Temajuk Village as a coastal border area.

(8) Creating a model of developing economic empowerment and ecotourism in coastal border villages based on technological innovations such as for the provision of solar-powered electricity facilities, processing of organic and non-organic waste, packaging and labeling of business products, promotion strategies and marketing through social media or information media.

As according to similar studies by Ginting (2013), Sulaiman (2013), Raheem (2016), Wulandari (2016), Silmi (2017), Puspaningrum \& Agustina (2017), Zakaria et al (2018), Sulaiman et al (2019) that the research process that uses participatory methods, has similarities in the stages of the process such as (1) The activity of opening access, approaches and permits to the research location, this is to establish closeness, acceptance, openness and there is no distance between the researcher and the informant. so that the research process will be smooth, get support and obtain the expected results. (2) Interview, observation and documentation data collection activities are carried out in a closer, dialogical, informal, participatory and harmonious way. (3) research activities based on the results of deliberation, agreement and involvement of all parties, so that starting from the planning, implementation, and evaluation of the activities carried out together. (4) Research establishes a close relationship, continued sustainability. Although the research activities are finished.

Thus an illustration of the participatory research process can be made as follows in figure 1 .

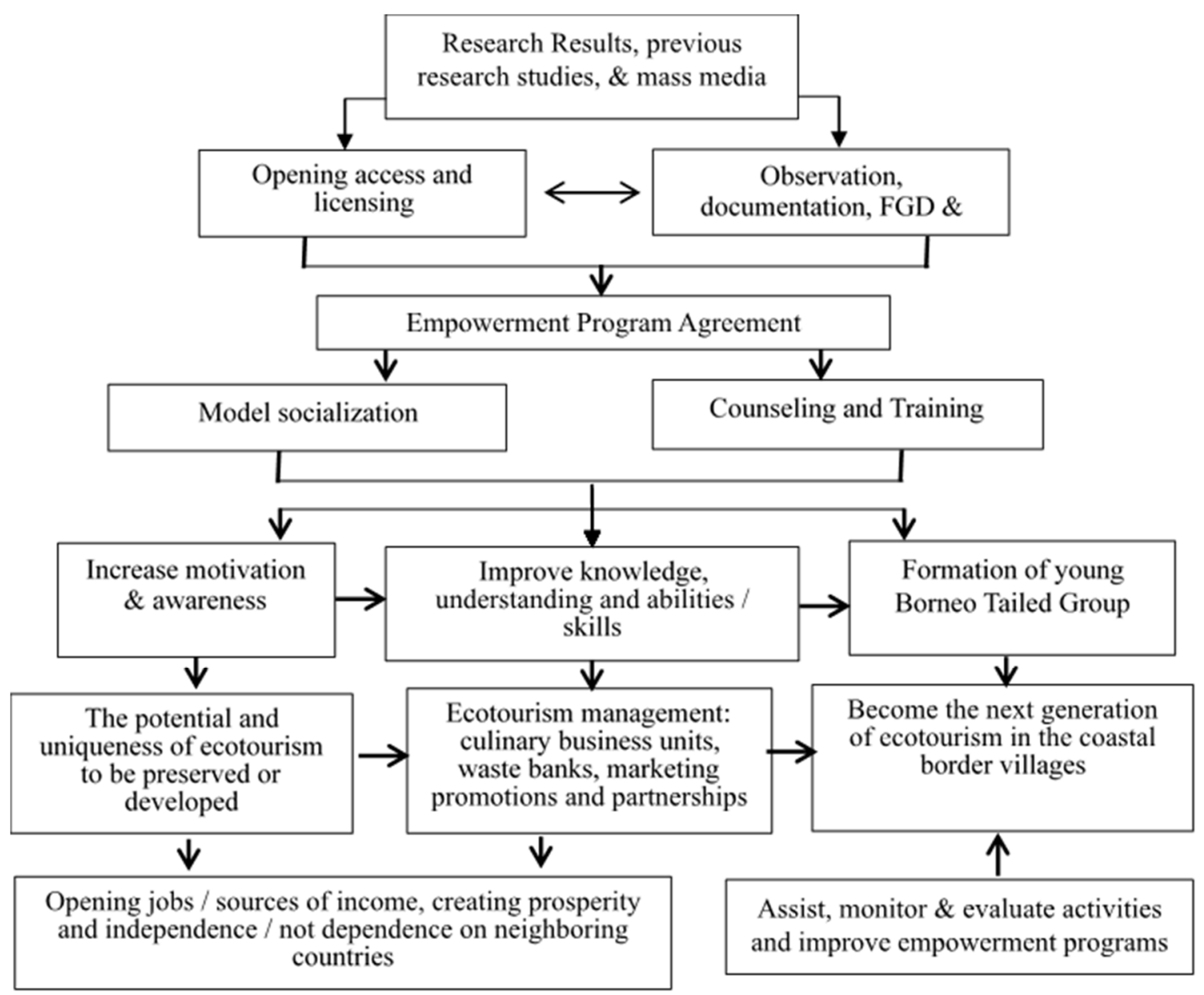

Figure 1. Research Process of Ecotourism Empowerment in Coastal Border Village 


\subsection{Implementation of the Ecotourism Empowerment Model in the Coastal Border Village}

Temajuk Village has the potential and attractiveness as a unique natural tourist destination, so that it can be developed, such as the location of the Tugu Garuda monument, Surya beach tour, coral reef location, Maludin beach, Mangrove Forest, Gunung Pangi Waterfall, Camar Bulan Pier, Atong Bay, Batu Grandma, Batu Bajula Pasir Plaik, and Tanjung Datok. The location is in one area in Temajuk Village which is still natural, beautiful, and comfortable. This is supported by the potential of abundant marine fish products that can be used as a typical tourist food.

Sambas Regency, West Kalimantan Province was designed in a participatory manner by community and youth leaders, environmental activist empowerment activists, business actors, village government, and academics to deepen and construct the problems faced, potentials and prospects that can be developed. The target of ecotourism empowerment is students high school in Temajuk Village that were chosen as representatives of the younger generation, the next generation, as activists and pioneers who will mobilize other youth communities to be able to protect, preserve and develop the potential for ecotourism in Temajuk Village as a coastal border area.

Before implementing the ecotourism empowerment model, the researcher conducted further identification and analysis especially on the participants or research informants of 25 students with a participatory method through the Problem Based Learning (PBL) approach, Discovery Leanrning and the Project Based Learning method. The results are namely (1) having knowledge and understanding of tourism potential and its environment as proven to be able to mention and full describe such as the type or category of tourism, tourist routes and locations in Temajuk Village. (2) Having a high motivation and motive to be able to play a role as a tourist business by protecting, preserving and wanting to develop the potential of ecotourism that is to become a tour guide, culinary business and promotion and marketing team. (3) Being able to identify existing problems regarding the development of ecotourism while providing a concept of solution. (4) Willing to form a tourism-conscious generation group with the name Borneo Tail groups to carry out the role of a tour guide, culinary business and promotion and marketing team. (5) Able to simulate the process of creating an ecotourism development program.

Implementation of the empowerment of ecotourism were not only in the form of socialization, counseling, simulation and training, but also emphasizing the research subjects to carry out ecotourism development. They require assistance and cooperation or partnerships among all stakeholders such as government, community, educational institutions and non-governmental organizations, and business actors.

According to Purnamasari et al. (2016) and Arismiyanti (2017) strategies that can be applied in the development of sustainable marine ecotourism in Indonesia are: regional development and marine ecotourism products through empowering local communities; network development of the marine and tourism industry; infrastructure development; marketing marine ecotourism products; marine spatial planning; increasing the security of marine tourism; and the development of institutions and human resources. Sabahan and Evita (2017) state that Sebubus and Temajuk villages in Paloh sub-district have prospective tourism potential, thus they require local government policy to establish a coastal ecotourism area with more attention to nature protection and cultural preservation, as well as the empowerment of ecotourism for the community in order to be able to further enhance community participation and welfare.

Dewi and Rachmawati (2018) suggest strategies in empowering coastal border communities, are (1) Increasing participation, especially youth and women, (2) Forming and developing tourism-aware groups in the community by monitoring, evaluating and assisting (4) Developing arts festivals , culture and economic endeavors on the border as a medium for promotion, interaction, marketing and cooperation. Whereas Rhama (2018) emphasized that global ecotourism has become an alternative for the tourism sector while still protecting and preserving the environment, as well as being beneficial to improve the living standards of local people.

Therefore in the implementation of ecotourism empowerment, it can be formulated and given the assistance and partnership program recommendations in Table 1 below:

Table 1. Implementation of the Coastal Border Community Empowerment Model

\begin{tabular}{|c|c|}
\hline Empowerment Program & Assistance and Partnership \\
\hline $\begin{array}{l}\quad \text { Study and FGD on previous } \\
\text { research findings }(2018-2019) \\
\checkmark \text { Socialization of the outer coastal } \\
\text { border empowerment model to } \\
\text { empowering participants who are }\end{array}$ & $\begin{array}{l}\checkmark \text { Partnership from the Center for Rural and Border Area } \\
\text { Development Studies from lecturers / colleagues of Tangjungpura } \\
\text { University (Untan) by conducting research FGDs and recommending } \\
\text { empowerment of young people in coastal border villages } \\
\checkmark \text { Partnership from the village government to allow and support }\end{array}$ \\
\hline
\end{tabular}




\begin{tabular}{|l|}
\hline students high school \\
$\checkmark$ Group discussion on identifying and \\
analyzing ecotourism issues, \\
potentials and prospects in Temajuk \\
Village \\
$\checkmark \quad$ Apply Brainstorming, Problem \\
Based Learning (PBL),Discovery \\
Learning, and Project Based Learning \\
\hline$\checkmark$ Counseling and training in strategy \\
management and ecotourism \\
development \\
$\checkmark$ Counseling and training in culinary \\
entrepreneurship management typical \\
of both drinks and food \\
$\checkmark$ Formation of youth tourism \\
awareness groups (Ekor Borneo \\
groups) \\
$\checkmark$ Discovery Learning, and Project \\
Based Learning method \\
Sour Aung or
\end{tabular}

extension activities and ecotourism management training

$\checkmark$ The Paloh 2 Public High School in Temajuk Village supports and hosts ecotourism management education and training activities

$\checkmark$ Empowerment activists at Pelangi Agriculture groups became instructors and resource persons in ecotourism training and training activities.

$\checkmark$ The activists of Tanjungpura University (Untan) alumni empowerment, who are native of the Sebubus and Temajuk villages, are the assistants in the development of ecotourism.

$\checkmark \quad$ The village government allows and supports activities and by sending representatives

$\checkmark$ Empowerment activists at Pelangi Agriculture groups became instructors and resource persons in ecotourism training and training activities.

$\checkmark \quad$ The Paloh 2 Public High School in Temajuk Village supports and hosts ecotourism management education and training activities

$\checkmark$ The activists of Tanjungpura University (Untan) alumni empowerment, who are native of the Sebubus and Temajuk villages, are the assistants in the development of ecotourism.

Source: Author's own work

The implementation of research using the Participatory Action Research (PLA) method through the implementation of ecotourism empowerment for students as young generation is very important and effective because of high motivation, curiosity and solidarity as evidenced from the enthusiasm and active role of students as participants in the series of stages of empowerment activities, including the process and evaluation results with participants. The younger generation is expected to play an active role in continuing and developing and become agents of change for the development process in rural communities in this case the development of ecotourism potential.

However, in the implementation of empowerment, there are still obstacles that must be overcome, namely

(1) Implementation of empowerment must be carried out sustainably, comprehensively, synergistically and collaboratively, meaning that the implementation so far is only partial in nature, both from the implementer or organizer, the material program and the time of implementation. So that it needs to be periodically carried out by all stakeholders both the village government, empowerment activists, academics, non-governmental organizations and the private sector.

(2) Empowerment programs are technocratic programs, meaning that they are not based on participatory approaches based on the results of studies or research on the problems, potentials, needs and prospects of the community. So that research-based empowerment needs to be designed.

(3) Empowerment is not just an increase in motivation, knowledge and skills, but there is the formation, development and strengthening of institutions, the ability to create and propose empowerment programs, able establish partnerships or cooperation. Empowerment can create jobs for young people themselves and society in general, reducing urbanization and migrant workers to neighboring Malaysia.

There is an integrated concept of coastal management as an effort to unite government with the community, science with management, and sectoral interests with the interests of the community in implementing integrated program planning for the protection and development of coastal ecosystem resources so that there is an improvement in the quality of life of the communities in the coastal area as well can maintain the biodiversity and productivity of coastal ecosystems (Darmawan 2001).

The empowerment is not only to increase motivation or determination and willingness, as well as knowledge, skills, but also can maintain the preservation of nature and the environment (ecology) that is natural, balanced and maintained (Pigawati 2005). Empowerment can also create productive economic activities in the border region based on local resources that are carried out in a sustainable manner by paying attention to resource capacity (Lasabuda 2013). Ecotourism development programs in coastal areas must also be in accordance with efforts to protect and preserve the environment or overall conservation (Witomo 2019). Then the form of empowerment 
cannot be separated from cooperation or partnership to achieve prosperity and independence and eventually become an empowerment actor (Sulaiman et al. 2019);(Kour 2018).

Economic empowerment and ecotourism on the border coast as a prospective local potential, has not been a serious concern for village and regional governments which generally in infrastructure and development programs are more inclined to the development of commercial areas. So that the government can focus on the development of regional development, especially road access facilities, electricity and telecommunications media (internet) in the coastal border areas and educational institutions such as high schools and vocational schools can make economic empowerment and ecotourism into additional, optional and compulsory subjects as local content that is unique and has characteristics as local wisdom.

Coastal border areas are actually a reflection of developmental development and betting on national sovereignty, as according to Djunaedi (2002) development in coastal border areas that have potential problems and conflicts need to run the Intergrated Coastal Zone Management model or manage the whole program as a whole. Adam et al. (2012) describes development in border and outermost coastal areas concerning national sovereignty. Moreover, the development of the coastal border areas of the border is not only about regional sovereignty, defense and security, but also must realize food, economic, and social sovereignty that guarantees the welfare and independence of the nation.

Muazir and Hsieh (2013) emphasized that cooperation and competition between the Kedia regions in Sarawak Malaysia and West Kalimantan cannot be avoided, but promoting cooperation is better, such as from the tourism and economic sectors with the provision of markets that can mutually benefit and support each other. Druzhinin eta al. (2016) stated that the problem of the outermost border region must receive serious attention and be evaluated because it is related to the crisis and changes in the geo-political and geo-economic situation that will have an impact on the regional economy. Likewise according to Kotsoni et al. (2017) it requires seriousness of government decisiveness with its policy regulations as well as public awareness and control of the development of tourist facilities in the coastal boundary, in order not to damage the environment and ecosystem.

Therfore the implementation of empowerment program and further research can be formulated as in Table 2 below:

Table 2. Implementation of Empowerment Program and Further Research

\begin{tabular}{|c|c|}
\hline$\checkmark$ Empowerment Research Program & $\begin{array}{l}\checkmark \text { Implementation of the Coastal Border Ecotourism } \\
\text { Empowerment Research in Temajuk Village }\end{array}$ \\
\hline $\begin{array}{l}\checkmark \text { Business management in the form of } \\
\text { all-round cooperative business }\end{array}$ & $\begin{array}{l}\checkmark \text { Increase motivation, role and ability in strategies to increase } \\
\text { income, promotion and marketing of community products in the } \\
\text { form of a joint venture that is cooperative }\end{array}$ \\
\hline $\begin{array}{l}\checkmark \text { The development of the Borneo } \\
\text { Tailed young tourism group is better } \\
\text { able to adopt information technology } \\
\text { innovations on Social Media and } \\
\text { Community Radio }\end{array}$ & $\begin{array}{l}\checkmark \text { Improved group dynamics and ecotourism management, } \\
\text { especially promotion and marketing }\end{array}$ \\
$\checkmark \begin{array}{l}\text { The establishment of community radio by forming an editorial } \\
\text { team from the Borneo Tailed group for public information and } \\
\text { communication media }\end{array}$ \\
\hline $\begin{array}{l}\checkmark \text { Waste management becomes a waste } \\
\text { bank business group }\end{array}$ & $\begin{array}{l}\checkmark \text { Analysis and comparative study to build a waste bank and waste } \\
\text { management }\end{array}$ \\
\hline $\begin{array}{l}\checkmark \text { Providing electricity facilities with } \\
\text { solar power }\end{array}$ & $\begin{array}{l}\checkmark \text { Conduct a feasibility study and the realization of the installation } \\
\text { of solar powered electricity as energy independence }\end{array}$ \\
\hline
\end{tabular}

Source: Author's own work

Based on the process stages, implementation, monitoring, evaluation, analysis and discussion of results, as well as an advanced empowerment research agenda, it can be made the development of a model of coastal border ecotourism empowerment in Tamajuk Village, Paloh District, Sambas Regency, West Kalimantan as a recommendation for development and research, study, community service and public activities.

The development of the outer coastal border areas are very important and strategic, according to Pauwelussen (2016) and Obidzinski et al. (2007), such as the case of forest destruction on the border requires serious attention between the two regions of the border Indonesia and Malaysia so that the preservation of the environment and the reforestation of the ecosystem is maintained. Putra (2010) emphasized that there are substantial values in border 
areas such as the value of sovereignty, integrity, agreement, ideology, equality, cooperation, legal certainty, and mutual respect, the value of state development and cooperation, economic values and welfare, social, cultural, politics, security, geographical, spatial and technological value.

The development of the ecotourism-based coastal border area is important especially in the development there needs to be a balance of protection and preservation of natural resources or the environment, especially marine biota such as coral reefs and animals (Pranajaya \& Wardhani 2012), because the growth of coastal tourism will affect the development of other sectors such as economic and social issues, including the threat of environmental damage (Latif et al. 2012).

Policies are needed in various sectors and levels regarding the impacts of climate change and the environment in coastal border areas which have been prioritized in the fields of marine, fisheries and disaster management (Bengen \& Tahir 2013). Yet it should be highlighted the basic needs of the community that needs support from development policies to realize integrated coastal autonomy that can improve economic life by becoming a center for production, processing and marketing, especially fisheries and the service sector (Darmanto 2013) (Sutrisno 2014).

Moreover the development of the coastal border areas can realize a prosperous and independent coastal border area (Widodo et al. 2015). The strategy of developing ecotourism in coastal areas is by empowering based on the utilization of natural potential such as mangrove forests, mangroves, fisheries and the beauty of the coast and is supported by the preservation of local wisdom of the community (Hakim et al. 2017); (Talib 2018). The development of the coastal border empowerment model is as follows:

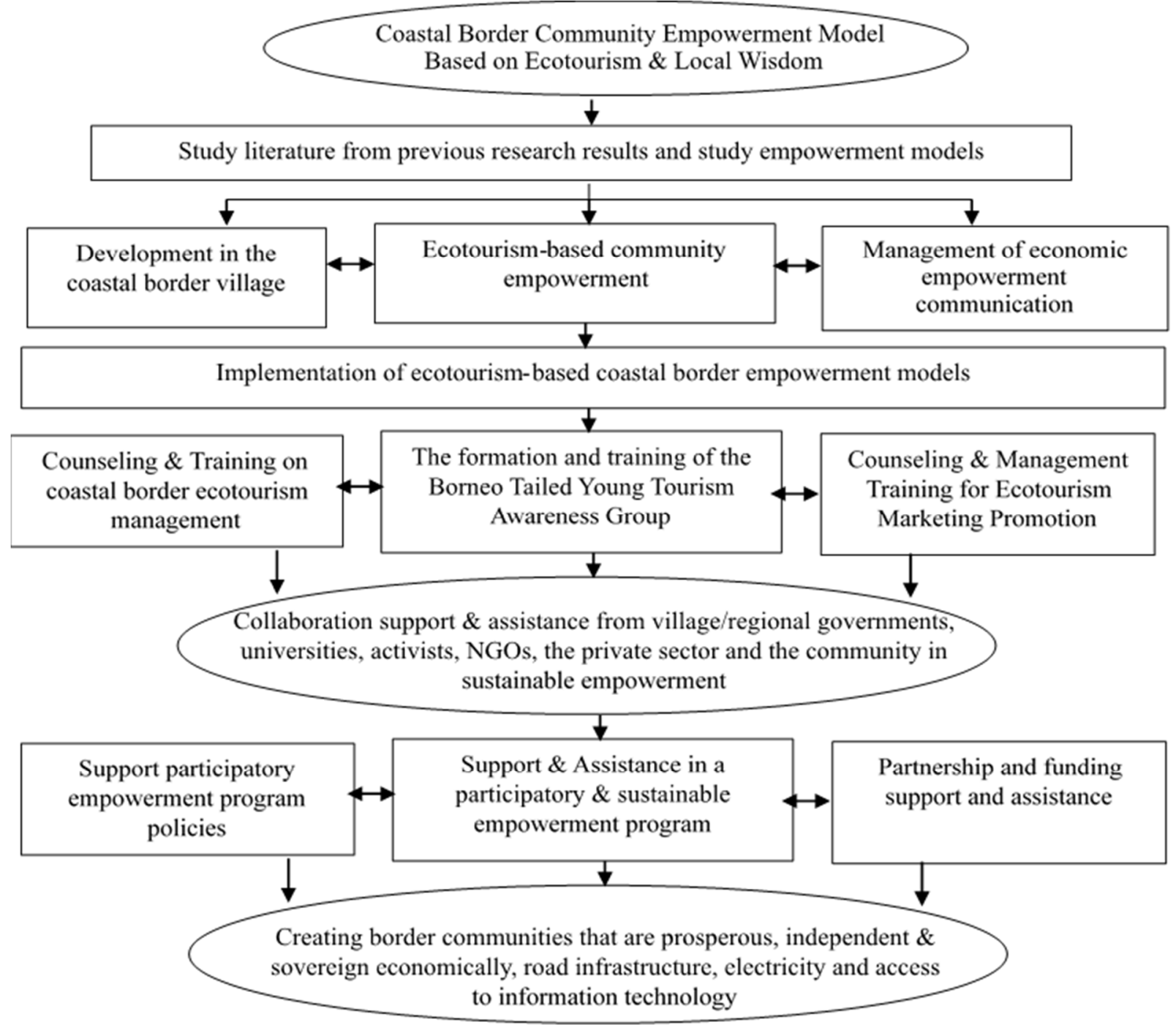

Figure 2. The development of the coastal border empowerment model 


\section{Conclusion}

Problems and challenges in the coastal border areas of Temajuk Village still require serious attention, especially road access facilities, availability of electricity, and information telecommunications networks (internet) that are still lagging behind neighboring areas namely Melano in Malaysia. More over the people of Temanjuk are still dependent on finding work in neighboring Malaysia to become farm laborers in oil palm plantations, rubber plantations, livestock, construction laborers, carpenters, and domestic servants, including dependence on daily needs that are more complete, inexpensive and easily available in Melano Malaysia.

Planning and implementing empowerment of the outer coastal border ecotourism in Temajuk Village is still partial and technocratic, so that it requires participatory, research-based and synergistic empowerment among stakeholders, namely village and regional governments, academics of higher education, communities, business groups, empowerment activists and the private sector.

Empowerment can be designed and implemented continuously based on studies and research so that it is in accordance with the problems, potential, needs and prospects of human resources (the community), environmental (natural) resources, socio-economic and cultural resources.

The young generation can become the successor of tourism awareness groups under the name of Pokdarwis Ekor Borneo through an empowerment program to increase motivation, awareness, knowledge, and natural expertise to protect and preserve the potential of the outer coastal border ecotourism.

Empowerment of the younger generation is expected to be carried out comprehensively starting from participatory planning, counseling, training, monitoring and evaluation, comparative studies, mentoring to partnerships, increasing welfare, independence and the formation of new empowerment agents.

Continuation of the empowerment program for the development of coastal border ecotourism is carried out by counseling and training cooperative management as a community economic institution, management of the waste bank as a new business unit, management of tourism promotion and marketing strategies, and technological innovations in the provision of solar powered electricity.

Development in the coastal border villages is a reflection of the advancement of development and betting on national sovereignty, not only mandatory to uphold regional sovereignty, defense and security, but also to be able to realize food, economic, and social sovereignty that guarantee the welfare and independence of the nation.The results of the research, academically, are that community empowerment is not only intended for economic development, economic equality, and the establishment of economic business institutions. But empowerment can aim for social engineering, strengthening nationalism and environmental awareness. The practical implication is that empowerment becomes a development medium that unites participatory community interests with the interests of technocratic elites.

Then the novelty of this research as a contribution of research results is to creat the development of empowerment models in the coastal border villages by forming institutions of the young generation as the next generation to be able to protect, preserve and develop the potential of ecotourism in their villages.So far, there has never been any research that focuses on this, mostly research into the territorial and infrastructure, government policies and economic business groups.

The results of the study are very useful in providing recommendations for policy making especially school education curricula that must include environmental awareness, coastal economy, ecotourism and tourism management materials.

The results of the study are very useful in providing recommendations for policy making in government and leaders in schools, especially school education materials to become educational curriculum as a choice subject or local content, namely environmental, coastal economy, ecotourism and tourism management.

Suggestions for the government, schools, researchers and practitioners that need to focus interest of the younger generation as the next generation to be targeted by empowerment programs. so that it will form a cadre of the next generation of development in the village. Theoretically, research on coastal borders can also be examined in terms of intercultural communication theory, dependency theory, and development theory. 


\section{Acknowledgments}

Thank you for Ministry of Research, Technology and Higher Education of the Republic of Indonesia and Institute for Research and Community Services of Jenderal Soedirman University in Indonesia for providing opportunities and support for our applied research. Hopefully it could be contribute to the development of science, scientific studies, community service and further research. We would also thank for the support and participation of the village government, research informants from the empowerment activists, empowerment participants from students high school and the Headmaster of Sebubus High School in West Kalimantan.

\section{References}

Adam, L., Sihombing, L., Pujiyanti, A., Haryanti, D., \& Nainggolan, P. P. (2012). Wilayah Pesisir dan PulauPulau Kecil di Indonesia. Jakarta: Pusat Pengkajian, Pengolahan Data dan Informasi (P3DI) Sekretariat Jenderal DPR Republik Indonesia dan Azza Grafika.

Arismiyanti, N. K. (2017). Development Strategy of Ecotourism Marine Sustainable in Indonesia. Asean Journal on Hospitality and Tourism, 15(2), 118-138.

Ashary, L. (2016). Optimalisasi Pemberdayaan Karangtaruna dalam Pengembangan Desa Silomukti Kabupaten Situbondo. Prosiding Seminar Nasional: Dinamika Global: Rebranding Keunggulan Kompetitif Berbasis Kearifan Lokal. Universitas Jember, 725-738.

Bengen, D. G., \& Tahir, A. (2013). Policy Review: Opportunities for Enhancing Coastal Community Resilience and Climate Change Adaptation in Indonesia. This publication was produced for review by the United States Agency for International Development. It was prepared by Bogor Agricultural University (IPB) and the Coastal Resources Center, Graduate School of Oceanography, University.

Bintari, P. N., \& Darmawan, C. (2016). Peran Pemuda sebagai Penerus Tradisi Sambatan dalam Rangka Pembentukan Karakter Gotong Royong. Jurnal Pendidikan Ilmu Sosial, 25(1), 57-76. https://doi.org/10.17509/jpis.v25i1.3670

Darmawan. (2001). Penyusunan Program Pengelolaan Wilayah Pesisir dan Pulau-pulau Kecil Secara Terpadu. Prosiding Pelatihan Pengelolaan Wilayah Pesisir Terpadu. Pusat Kajian Sumberdaya Pesisir dan Lautan Institut Pertanian Bogor, 29 Oktober - 3 November 2001, 1-13.

Dewi, M. A., \& Rachmawati, I. (2018). Kendala dan strategi pengembangan kawasan wisata perbatasan IndonesiaPapua Nugini di Sota Kabupaten Merauke. Masyarakat, Kebudayaan dan Politik, 31(4), 400409. https://doi.org/10.20473/mkp.V31I42018.400-409

Dharmasaputra, R. (2009). Manajemen dan Reformasi Sektor Keamanan. Jakarta: IDSPS Press.

Djunaedi, A. (2002). Perencanaan Pengembangan Kawasan Pesisir. Jurnal Teknologi Lingkungan, 3(3), 225231. https://doi.org/10.29122/jtl.v3i3.259

Druzhinin, A. G., Lachininskii, S. V., \& Mikhaylov, A. S. (2016). The Factors and Possibilities of CrossBorder Clusters Development in A Coastal Zone of Russia of The Black and The Baltic Sea. Conference Proceedings, 3rd International Multidisciplinary Scientific Conference on Social Sciences and Arts $\begin{array}{llll}\text { SGEM 2016. http://www.sgemsocial.org, } & \text { 755-762, }\end{array}$ https://doi.org/10.5593/SGEMSOCIAL2016/B25/S07.099

El Hasanah, L. N. (2015). Pengembangan Wirausaha Muda Ekonomi Kreatif Berbasis Budaya di Daerah $\begin{array}{lllll}\text { Istimewa Yogyakarta. Journal Studi Pemuda, } & \text { 4(2), }\end{array}$ https://doi.org/10.22146/studipemudaugm.36812

Firdaus, M., \& Rahadian, R., (2018). Peran Sektor Perikanan Pada Wilayah Pesisir Perbatasan Kalimantan Barat. Jurnal Sosial Ekonomi Kelautan dan Perikanan, 13(1), 15-27. https://doi.org/10.15578/jsekp.v13i1.6843

Ginting, A. M. (2013). Kendala Pembangunan Provinsi Daerah Kepulauan: Stud Kasus Provinsi Kepulauan Riau. Politica, 4(1), 49-75. https://doi.org/10.22212/jp.v4i1.328

Hakim, L., Siswanto, D., \& Makaghosi, N. (2017). Mangrove Conservation in East Java: The Ecotourism Development Perspectives. Journal of Tropical Life Science, 7(3), 277-285, https://doi.org/10.11594/jtls.07.03.14 
Hassan, M. I., \& Rahmat, M. H. (2016). The Effect of Coastline Changes to Local Community's SocialEconomic. The International Archives of the Photogrammetry, Remote Sensing and Spatial Information Sciences, XLII-4/W1, 2016 International Conference on Geomatic and Geospatial Technology (GGT) 2016, 3-5 October 2016, Kuala Lumpur, Malaysia, 25-36. https://doi.org/10.5194/isprs-archives-XLII4-W1-25-2016

Itika, J. S. (2016). Fundamentals of human resource management Emerging experiences from Africa. African Public Administration and Management series, 2. Leiden: African Studies Centre.

Khairunnisa., Fahrudin, A., \& Kusumastanto, T. (2017). Penilaian Ekonomi Wisata Pesisir Kawasan Carocok Painan, Kabupaten Pesisir Selatan, Sumatera Barat. Jurnal Ekonomi dan Pembangunan Indonesia, 18(1), 1-21. https://doi.org/10.21002/jepi.v18i1.672

Kotsoni, A., Dimelli, D., \& Ragia, L. (2017). Land Use Planning for Sustainable Development of Coastal Regions. Proceedings of the 3rd International Conference on Geographical Information Systems Theory, Applications and Management (GISTAM 2017), 290-294. http://doi.org/10.5220/0006370802900294

Kour, F. (2018). Kajian ekonomi dan kebijakan pengelolaan Pulau Lirang, Maluku Barat Daya, Indonesia. Journal Akuatikisle, 2(1), 22-29. https://doi.org/10.29239/j.akuatikisle.2.1.22-29

Kumar, S. (2002). Methods for Community Participation: A complete guide for practitioners. London: ITDG Publishing.

Lasabuda, R. (2013). Pembangunan Daerah Pesisir dan Lautan dalam Perspektif Negara Kepulauan RI. Journal Ilmiah Platax, 1(2), 92-101. https://doi.org/10.35800/jip.1.2.2013.1251

Latif, T. A., Ramadan, S. T., \& Galal, A. M. (2012). Egyptian coastal regions development through economic diversity for its coastal cities. HBRC Journal, 8(3), 252-262, https://doi.org/10.1016/j.hbrcj.2012.10.009

Miles. M. B., Huberman, A. M., \& Saldana, J., (2014). Qualitative Data Analysis A Methods Sourcebook: Edition 3. Los Angeles, London, New Delhi, Singapore \& Washington DC: SAGE Publication.

Muazir, S., \& Hsieh, H. C. (2013). Borderlands and Tourism Development in Kalimantan Island: Kalimantan Barat, Indonesia - Sarawak, Malaysia "Head to Head". Journal of Design and Built Environment, 13(1), 1-12. https://ejournal.um.edu.my/index.php/jdbe/article/view/5336

Nugroho, M.A. (2011). Pemberdayaan Pulau Terluar Tidak Berpenghuni Di Sekitar Selat Malaka Dalam Meningkatkan Ketahanan Negara (Perspektif Strategis Ketahanan Nasional). Tesis. Universitas Indonesia.

Obidzinski, K., Adriyanto, A., \& Wijaya, C. (2007). Cross-border timber trade in Indonesia: critical or overstated problem? Forest governance lessons from Kalimantan. International Forestry Review, 9(1), 526-535. https://doi.org/10.1505/ifor.9.1.526

Okoli, D. I., \& Okoli, E. I. (2013). Youth Empowerment through Entrepreneurial Development in Nigeria. Journal of Educational and Social Research, 3(9), 147-151. https://doi.org/10.5901/jesr.2013.v3n9p147

Oyekan, S. O. (2015). The Role of Orientation in Youth Empowerment for National Development.European Journal of Social Science Education and Research, 2(4), 297-310, https://doi.org/10.26417/ejser.v5i1.p297-310

Pauwelussen, A. (2016). Community as network: exploring a relational approach to social resilience in coastal Indonesia. Maritime Studies, 5(2), 1-19. https://doi.org/10.1186/s40152-016-0041-5

Pigawati, B. (2005). Identifikasi Potensi dan Pemetaan Sumberdaya Pesisir Pulau - Pulau Kecil dan Laut Kabupaten Natuna - Provinsi Kepulauan Riau. Jurnal Ilmu Kelautan, 10(4), 226-239, http://10.14710/ik.ijms.10.4.229-236

Pranajaya, A., \& Wardhani, M. K. (2012). Kajian Pengelolaan Pesisir dan Laut Lintas Negara (Review Perbandingan Teluk Persia dan Indonesia). Jurnal Kelautan, 5(1), 8-14, https://doi.org/10.21107/jk.v5i1.929

Pretty, J. N., Guijt, I., Thompson, J., \& Scoones, I. (1995). A Trainer's Guide for Participatory Learning and Action. London: International Institute for Environment and Development.

Purnamasari, W., Kara, M. H., Sabri, M. A. R., \& Amiruddin, K. (2016). Perkembangan Pembangunan Ekonomi Kawasan Perbatasan Negara Indonesia Malaysia Di Sambas. Jurnal Diskursus Islam, 4(2), 217-247. https://doi.org/10.24252/jdi.v4i2.7364 
Puspaningrum, D., \& Agustina, T. Pendekatan Pra (Participatory Research Appraisal) Dalam Pengembangan Kopi Arabika Specialty Ketinggian Sedang Bebasis Kawasan di Kabupaten Jember. Journal Agribest, 1(2), 187200. https://doi.org/10.32528/agribest.v1i2.1157

Putra, M. K. (2010). Politik Hukum Pembangunan Kawaesan Perbatasan Kesatuan Republik Indonesia Berbasis Teknologi Geospasial. Disertasi. Universitas Brawijaya.

Raheem, S, (2016). Review Paper Youth Empowerment Leveraging on Entrepreneurship. Wilolud Journals, 7(1), 45-60. https://doi.org/10.5707/cjsd.2016.7.1.45.60

Rhama, B. (2018). The Analysis of the Central Kalimantan Tourism Development Plan Based on Ecotourism Policy Perspective. Policy \& Governance Review, 2(3), 2580-4820. https://doi.org/10.30589/pgr.v2i3.110

Sabahan, \& Evita, R. (2017). Zonasi Lanskap Ekowisata Pesisir Kecamatan Paloh Kalimantan Barat. Jurnal Arsitektur Lansekap, 3(1), 32-38. https://doi.org/10.24843/JAL.2017.v03.i01.p04

Silmi, A. F. (2017). Participatory Learning And Action (PLA) di Desa Terpencil Peran LSM PROVISI Yogyakarta dalam Pemberdayaan Masyarakat di Lubuk Bintialo Sumatra Selatan. Jurnal Pemberdayaan Masyarakat: Media Pemikiran dan Dakwah Pembangunan, 1(1), 81-98. https://doi.org/10.14421/jpm.2017.011-05

Sulaiman, A. I. (2013). Model Komunikasi Formal dan Informal dalam Proses Kegiatan Pemberdayaan Masyarakat. Jurnal Penelitian Komunikasi, 16(2), 173-188. https://doi.org/10.20422/jpk.v16i2.38

Sulaiman, A. I., Masrukin, \& Suswanto, B. (2019). The Implementation of Community Empowerment Model as a Harmonization in the Village Traumatized by Terrorism Case. Jurnal Ilmiah Peuradeun, 7(1), 59-80. https://doi.org/10.26811/peuradeun.v7i1.257

Sutrisno, E. (2014). Implementasi Pengolahan Sumber daya Pesisir Berbasis Pengelolaan Wilayah Pesisir. Journal Dinamika Hukum, 14(1), 1-12. http://10.20884/1.jdh.2014.14.1.272

Talib, A. (2018). Peluang dan Tantangan Industri Teknologi Pengolahan Hasil Perikanan dalam Mendukung Terwujudnya Lumbung Ikan Nasional (LIN) di Maluku Utara. Jurnal Agribisnis Perikanan, 11(1). http://10.29239/j.agrikan.11.1.19-27

Van Geenhuizen, M., \& Rietveld, P. (2011). Land-borders and sea-borders: An exploration of differences in border region development. Journal of Borderlands Studies, 17(2), 63-77. https://doi.org/10.1080/08865655.2002.9695591

Wibawa, L. (2013). Pemberdayaan Pemuda Melalui Social Capital. Prosiding Seminar Nasional: Pengembangan Masyarakat Berbasis Modal Sosial. Yogyakarta: UNY, 137-142.

Widodo, P. W., Kurnia, R., \& Susilo (2015). Penilaian Pulau Kecil Sebagai Dasar Pengembangan Investasi Ekowisata (Studi Kasus Pulau Tidung Kecil, Kabupaten Kepulauan Seribu, DKI). Jurnal Sosial Ekonomi Perikanan dan Kelautan, 10(1), 77-90. http://dx.doi.org/10.15578/jsekp.v10i1.1249

Witarsa. (2015). Model Pengembangan Ekonomi Masyarakat Pesisir Berbasis Co-Manajemen Sumberdaya Perikanan di Kabupaten Pontianak. Journal Economia, 11(1), 26-46. http://10.21831/economia.v11i1.7752

Witomo, C. M. (2019). Pengelolaan Wilayah Pesisir Dengan Pendekatan Instrumen Ekonomi:Sebuah Review Teori dan Peluang Aplikasi. Buletin Ilmiah "Marina" Sosial Ekonomi Kelautan dan Perikanan, 5(1), 39-52. http://dx.doi.org/10.15578/marina.v5i1.7638

Wulandari, P. K. (2016). Generasi Sadar Wisata (Pemberdayaan Pemuda dan Pendidikan Duta Wisata di Kabupaten Tenggalek). Jurnal Sosiologi Pendidikan Humanis, 1(2), 140-148, https://doi.org/10.17977/um021v1i22016p140

Zakaria, Z., Sophian, R. I., \& Khoirullah, N. (2018). Modifikasi Konsep Participatory Rural Appraisal untuk Pembekalan Kuliah Kerja Nyata Mahasiswa di Jawa Barat Indonesia. Dharmakarya: Jurnal Aplikasi Ipteks untuk Masyarakat, 7(1), 38-45. https://doi.org/10.24198/dharmakarya.v7i1.14592

\section{Copyrights}

Copyright for this article is retained by the author(s), with first publication rights granted to the journal.

This is an open-access article distributed under the terms and conditions of the Creative Commons Attribution license (http://creativecommons.org/licenses/by/4.0/). 